\title{
FRACTURE INTENSITY IN THE PAVELOFF SILTSTONE MEMBER (CHINITNA FORMATION) AND POMEROY ARKOSE MEMBER (NAKNEK FORMATION), INISKIN PENINSULA, ALASKA: IMPLICATIONS FOR HYDROCARBON MIGRATION IN COOK INLET BASIN
}

\author{
Jacob L. Rosenthal ${ }^{1,2}$, Paul M. Betka ${ }^{1,3}$, Robert J. Gillis ${ }^{1}$, and Elisabeth S. Nadin ${ }^{2}$
}

\section{INTRODUCTION}

Recent field studies in the Iniskin-Tuxedni bays area of lower Cook Inlet, Alaska, seek to document the nature of fractures hosted in deformed forearc basin strata of Jurassic age (Rosenthal and others, 2015a, 2015b; fig. 9-1). This outcrop-based work relates to our understanding of petroleum systems in the underexplored hydrocarbon province of Cook Inlet and may serve as an analog for fracture intensity in the basin's subsurface. In this short paper we present preliminary results from two field localities, with one each in the Pomeroy Arkose Member of the Naknek Formation and the Paveloff Siltstone Member of the Chinitna Formation (fig. 9-1).

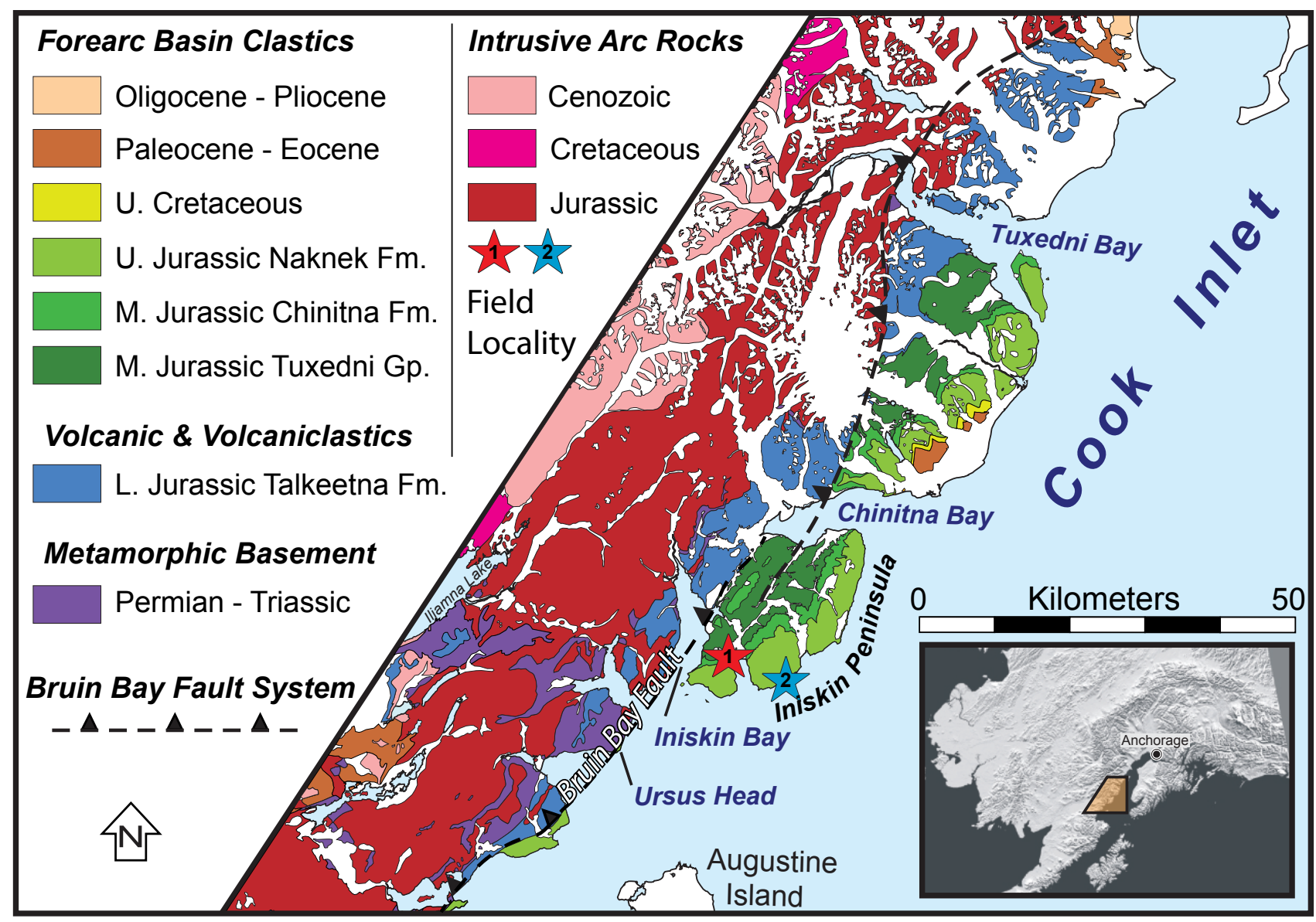

Figure 9-1. Simplified geologic map of the Iniskin-Tuxedni Bays region, lower Cook Inlet, Alaska, showing the trace of the Bruin Bay fault and distribution of Mesozoic-Cenozoic sedimentary rocks in the Cook Inlet forearc basin, volcanic and plutonic rocks of the Talkeetna arc and Alaska-Aleutian Range batholith, and Permian-Triassic metamorphic basement. Red and blue stars show locations of the two localities discussed in text: 1 = Paveloff Siltstone Member of the Chinitna Formation; 2 = Pomeroy Arkose Member of the Naknek Formation. Modified from Wilson and others (2012).

\footnotetext{
${ }^{1}$ Alaska Division of Geological \& Geophysical Surveys, 3354 College Rd., Fairbanks, AK 99709-3707; email for Jacob Rosenthal jilrose09@yahoo.com ${ }^{2}$ University of Alaska Fairbanks, Department of Geosciences - Geology, Geophysics and Geography, PO Box 755780, Fairbanks, AK 99775-5780 ${ }^{3}$ Now at Lamont-Doherty Earth Observatory, Columbia University, 61 Route 9W, Palisades, NY 10964
} 


\section{BACKGROUND}

Fractures serve as fluid conduits and control the migration of basinal fluids in strata where primary porosity and permeability were reduced during diagenesis (Engelder and others, 2009; Zeng and Li, 2009; Ortega and others, 2010), with large fractures ( $\geq 0.5 \mathrm{~mm}$ aperture) playing an especially important role in fluid migration (Laubach, 1997). Helmold (2013) demonstrated that Jurassic sandstones in lower Cook Inlet exhibit diminished primary porosity and permeability as a result of diagenesis, and oil shows and seeps in the region are often associated with major fractures that likely control the migration of hydrocarbons in the basin (Detterman and Hartsock, 1966; LePain and others, 2013; Wartes and Herriott, 2014; Alaska Oil and Gas Conservation Commission, 2015). Quantifying lithologic controls (for example, grain size) on the size and density of regionally mapped fracture sets is important for the development of tight sandstones in unconventional hydrocarbon plays. Understanding which parameters correlate with fracture size and density could enhance the economic potential of low permeability and porosity reservoirs in Jurassic strata of Cook Inlet.

\section{METHODS}

This study employs the size-normalized fracture intensity (number of fractures of a given size or larger) measurement scheme of Ortega and others (2006). We identified fracture sets at the two localities on the basis of fracture orientations, placed scan lines perpendicular to each set, and then measured the position and aperture (width) of every cement-filled fracture encountered along each scan line using a tape measure and logarithmically graduated fracture aperture comparator (figs. 9-2A, 9-2B, and 9-2C; Ortega and others, 2006).

The method of Ortega and others (2006) is a scale-independent approach to quantify fracture aperture distributions because it normalizes the cumulative number of fractures by the length of observation. Fracture aperture measurements for each scan line are sorted in descending order, starting with the largest. The cumulative number of fractures in each interval of measure (graduations on the comparator) are counted and normalized by the length of the scan line to determine the cumulative frequency per meter. Cumulative frequency versus aperture distributions fit power-law scaling relationships across three orders of magnitude (for example, Marrett and others, 1999). The power-law coefficient and exponent are determined by a least-squares regression; the coefficient represents the predicted number of fractures $1 \mathrm{~mm}$ or larger and the exponent is the slope of the regression, reflecting the abundance and range of fracture sizes (Ortega and others, 2006). We use the regression equation to compare fracture intensities from fracture sets at the two sampling locations to determine how fracture intensity correlates with lithology.

\section{RESULTS}

Three scan lines at locality 1 (fig. 9-1) were used to document the fracture intensity of three fracture sets (A, B, and C after Rosenthal and others, 2015a) in the Paveloff Siltstone Member (figs. 9-2A, 9-2B, and 9-3A). Scan line lengths were 14.98 $\mathrm{m}$ (number of fractures $[\mathrm{n}]=449), 4.75 \mathrm{~m}(\mathrm{n}=72)$, and $15.81 \mathrm{~m}(\mathrm{n}=62)$ for sets $\mathrm{A}, \mathrm{B}$, and $\mathrm{C}$, respectively. The mean strike and dip for each set is $340^{\circ} / 88^{\circ}$ (set A), $015^{\circ} / 88^{\circ}$ (set B), and $260^{\circ} / 82^{\circ}$ (set C) (fig. 9-2E). Fracture apertures ranged from 0.05 to $10 \mathrm{~mm}$ in all three sets. The fracture intensity coefficients for sets $\mathrm{A}, \mathrm{B}$, and $\mathrm{C}$ are $1.21,0.36$, and 0.29 , respectively. Fracture set $\mathrm{A}$ is the most intense at this location, followed by fracture set $\mathrm{B}$, and then set $\mathrm{C}$.

Two scan lines at locality 2 (fig. 9-1) document the fracture intensity of two fracture sets (A and B) in the Pomeroy Arkose Member (figs. 9-2D and 9-3B); fracture set $\mathrm{C}$ was present but was not measured at this locality due to extremely low fracture intensity and outcrop area. Scan line lengths were $35.48 \mathrm{~m}(\mathrm{n}=208)$ and $19.44 \mathrm{~m}(\mathrm{n}=103)$ for sets A and $\mathrm{B}$, respectively. The mean strike and dip for each set is $320^{\circ} / 89^{\circ}$ (set A) and $025^{\circ} / 83^{\circ}$ (set B) (fig. 9-2E). Fracture apertures ranged from 0.05 to $2.65 \mathrm{~mm}$ in both sets. The fracture intensity coefficients for sets A and B are 0.33 and 0.14 , respectively. Fracture set A has the highest intensity of fracture sets at this location, consistent with our observations at locality 1 .

Figure 9-2 (right). A. Scan line from the Paveloff Siltstone Member of the Chinitna Formation. Scan line oriented normal to the dominant fracture trending $340^{\circ}$ (set A). Geologist for scale. B. Detailed photograph of scan line from A, showing scanline oriented normal to prominent calcite-filled fractures of set A. C. Logarithmically gauged fracture aperture comparator used for quickly and accurately measuring fracture apertures in the field. Note: Not to scale. D. Scan line from the Pomeroy Arkose Member of the Naknek Formation. Scan line oriented normal to the dominant fracture set trending $320^{\circ}$ (set A). Cell phone (10 cm long; see red arrow) for scale. E. Rose diagrams representing the strike of fracture planes and contoured poles to fracture planes. 1. Rose diagram of fracture planes from the Paveloff Siltstone Member (locality 1). 2. Rose diagram of fracture planes from the Pomeroy Arkose Member (locality 2). 3. Overlay of the rose diagrams of 1 and 2, showing similarities between observed fracture sets at both locations (see fig. 9-1). 4. Poles to planes and rose diagrams for fracture data from both localities shown with Kamb contours in two standard deviation intervals. Note distribution of fracture poles to planes into well clustered fracture sets $A, B$, and $C$. 

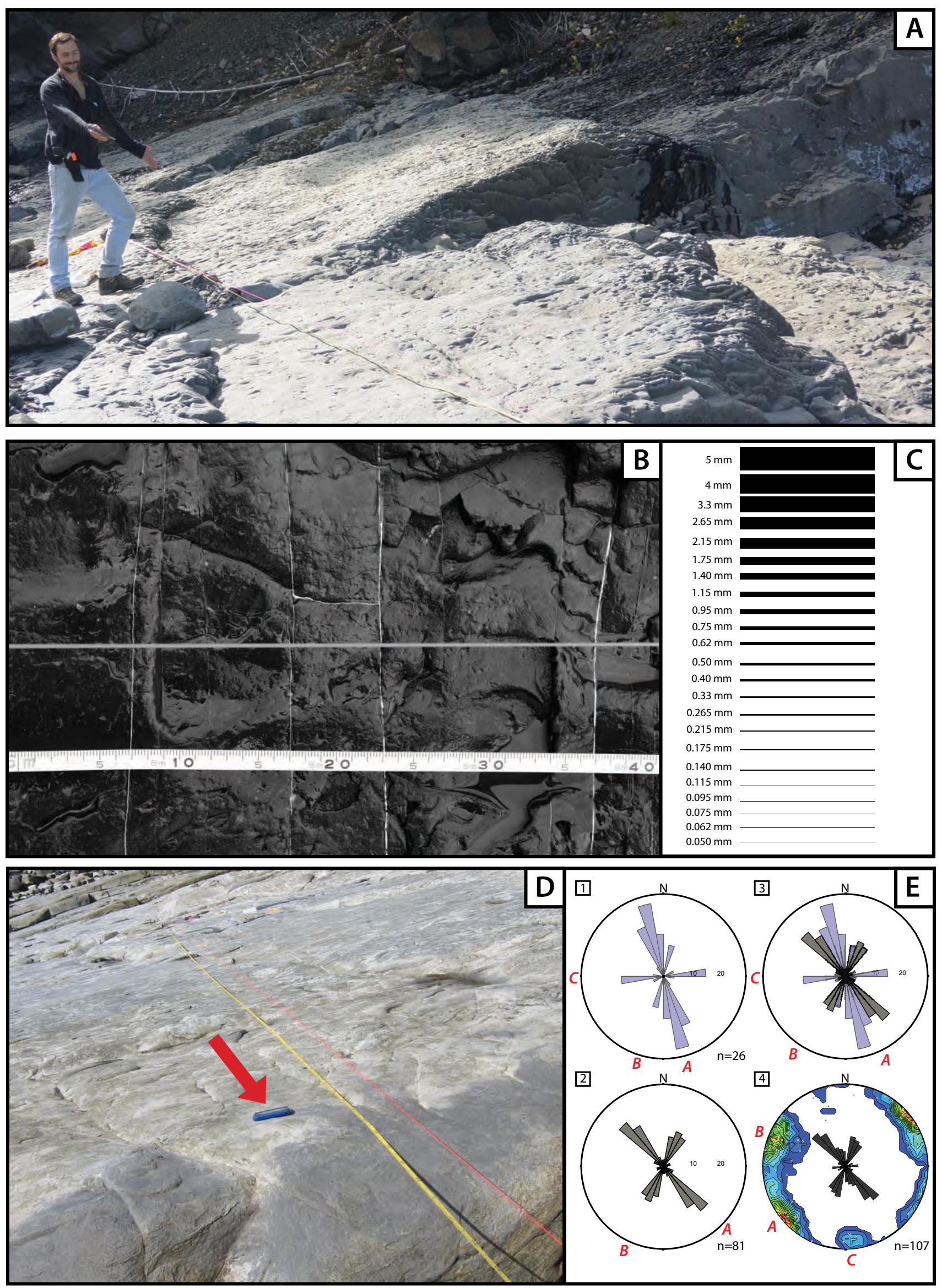

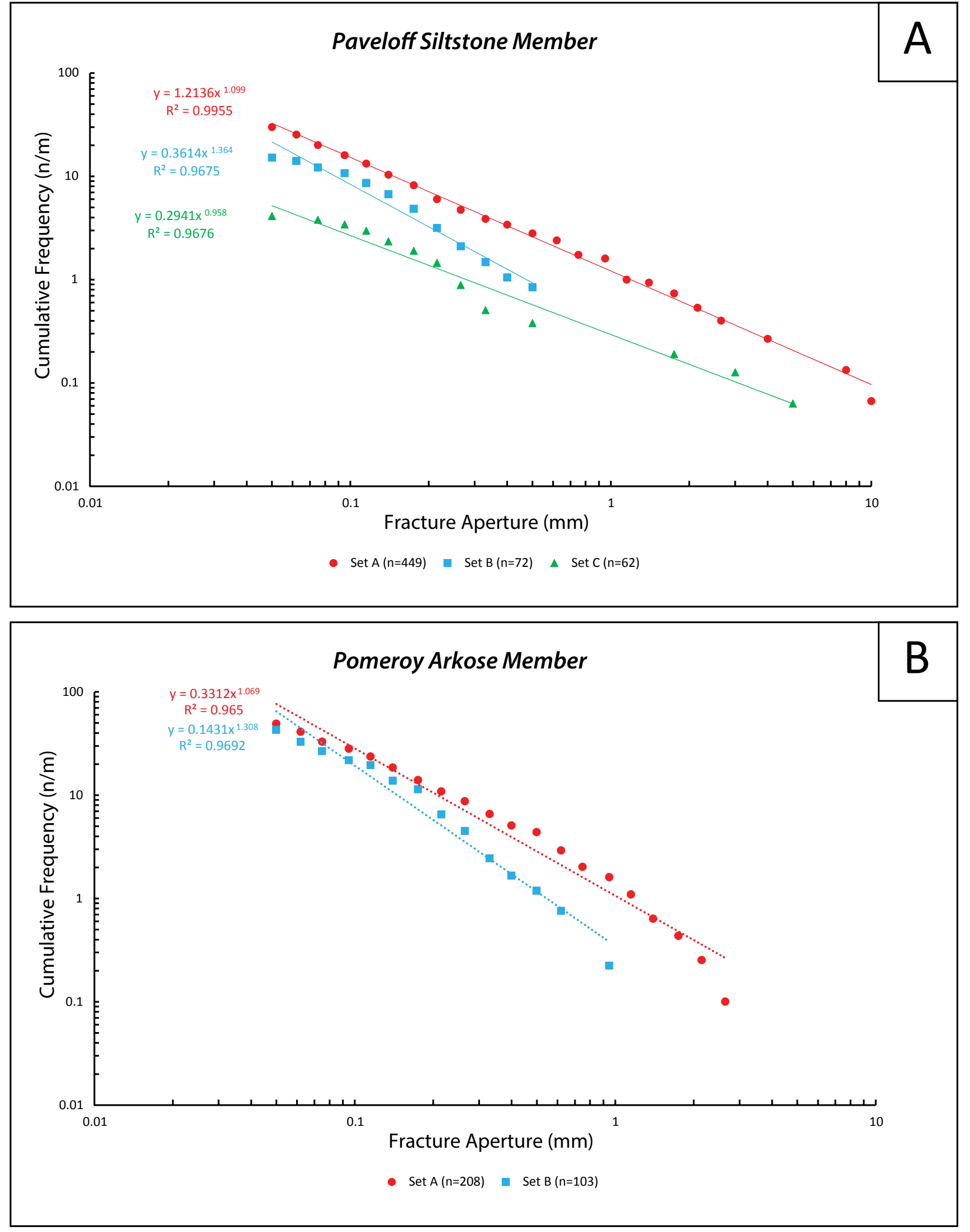

Figure 9-3. Fracture intensity data from scan lines at localities 1 and 2. A and B. Fracture set A (red) has the highest fracture intensity at both field sites discussed in the text, as shown by the higher coefficient reflecting a higher predicted number of fractures of 1 mm or larger per meter. Fracture set $B$ (blue) hosts the second highest fracture intensity at both locations. Fracture set $C$ (green) was only measured in the Paveloff Siltstone Member, and therefore no comparison can be made except to note that it is the least intense fracture set measured. Overall, the finer-grained Paveloff Siltstone has a higher fracture intensity than the coarser-grained Pomeroy Arkose. 


\section{SUMMARY AND CONCLUSIONS}

Fracture set $\mathrm{A}$ at both sampling localities is the most intense fracture set, followed by set $\mathrm{B}$ and then set $\mathrm{C}$ (measured only at locality 1). The Paveloff Siltstone hosts higher fracture intensities for each equivalent fracture set than does the Pomeroy Arkose. The Paveloff Siltstone is a finer-grained unit than the Pomeroy Arkose (Detterman and Hartsock, 1966) and we postulate that grain size is a primary control of fracture intensity variance between fracture sets of similar orientation at the two locations (compare with Nelson, 1985; Sinclair, 1980).

Rosenthal and others (2015b) establish that fractures trending $320^{\circ} \pm 10^{\circ}$ (set A) are the most pervasive and were observed from Tuxedni Bay to Iniskin Bay. Fracture set A has the largest fracture intensity documented by this study, and we suggest that these fractures may serve as important fluid migration pathways in the basin. Furthermore, the modern-day maximum principal stress - determined from stress tensor inversions of crustal earthquakes in the Cook Inlet region - trends southeast, approximately subparallel to set A (Ruppert, 2008). These data indicate that set A fractures would thus be the most likely to have served as natural fluid conduits under the modern stress regime in Cook Inlet. These observations also suggest that fracture set A would be the easiest to stimulate during drilling operations. Rosenthal and others (2015b) suggest that these fractures could have opened during Eocene ridge subduction, and therefore could have allowed for petroleum migration for the past 50 million years.

\section{ACKNOWLEDGMENTS}

This work is funded by the State of Alaska, with additional support by the U.S. Geological Survey's National Cooperative Geologic Mapping Program under STATEMAP award numbers G13AC00157 and G15AC00199. We thank Cook Inlet Region, Inc., and the Seldovia Native Association, Tyonek Native Corporation, Ninilchik Native Association, Salamatof Native Association, Knik Tribal Council, and Chickaloon Village, as well as Lake Clark National Park for land access permits. Snug Harbor Cannery provided excellent accommodations and logistical support during the field season. We thank our helicopter pilot, Merlin "Spanky" Handley, and Pathfinder Aviation for safe transportation during the field season. Trystan Herriott and Dave LePain provided constructive reviews that improved this paper. Special thanks to Paul Wilcox and Rebecca Tsigonis for assistance in the field.

\section{REFERENCES CITED}

Alaska Oil and Gas Conservation Commission (AOGCC), 2015, Well History Files On-line database. Last accessed November 17, 2015. http://aogweb.state.ak.us/WebLink8/Browse.aspx?dbid=0

Detterman, R.L., and Hartsock, J.K., 1966, Geology of the Iniskin-Tuxedni region, Alaska: U.S. Geological Survey Professional Paper 512, 78 p., 6 sheets, scale 1:63,360.

Engelder, Terry, Lash, G.G., and Uzcátegui, R.S., 2009, Joint sets that enhance production from Middle and Upper Devonian gas shales of the Appalachian Basin: AAPG Bulletin, v. 93, no. 7, p. 857-889. doi:10.1306/03230908032

Helmold, K.P., 2013, Reservoir quality of sandstones in the Naknek and Kaguyak Formations-Field observations, in Gillis, R.J., ed., Overview of 2012 field studies - Upper Alaska Peninsula and west side of lower Cook Inlet, Alaska: Alaska Division of Geological \& Geophysical Surveys Preliminary Interpretive Report 2013-1C, p. 11-12. doi:10.14509/24846

Laubach, S.E., 1997, A method to detect natural fracture strike in sandstones: AAPG Bulletin, v. 81, no. 4, p. 604-623. doi:10.1306/522B43E3-1727-11D7-8645000102C1865D

LePain, D.L., Stanley, R.G., Helmold, K.P., and Shellenbaum, D.P., 2013, Geologic framework and petroleum systems of Cook Inlet basin, south-central Alaska, in Stone, D.M., and Hite, D.M., eds., Oil and Gas Fields of the Cook Inlet Basin: American Association of Petroleum Geologists Memoir 104, p. 37-116.

Marrett, R.A., Ortega, O.J., and Kelsey, C.M., 1999, Extent of power-law scaling for natural fractures in rock: Geology, v. 27, p. 799-802. doi:10.1130/0091-7613(1999)027<0799:EOPLSF>2.3.CO;2

Nelson, R.A., 1985, Geologic analysis of naturally fractured reservoirs: Houston, Gulf Publishing, 320 p.

Ortega, O.J., Gale, J.F.W., and Marrett, R.A., 2010, Quantifying diagenetic and stratigraphic controls on fracture intensity in platform carbonates-An example from the Sierra Madre Oriental, northeast Mexico: Journal of Structural Geology, v. 32, p. 1,943-1,959. doi:10.1016/j.jsg.2010.07.004

Ortega, O.J., Marrett, R.A., and Laubach, S.E., 2006, A scale-independent approach to fracture intensity and average spacing measurement: AAPG Bulletin, v. 90, no. 2, p. 193-208. doi:10.1306/08250505059 
Rosenthal, J.L., Betka, P.M., Gillis, R.J., and Nadin, E.S., 2015a, Preliminary investigation of fracture populations in Mesozoic strata of the Cook Inlet forearc basin: Iniskin Peninsula and Lake Clark National Park, Alaska, in Wartes, M.A., ed., Energy-related studies during the 2014 field season, western Cook Inlet, Alaska: Alaska Division of Geological \& Geophysical Surveys Preliminary Interpretive Report 2015-5-3, p. 9-13. doi:10.14509/29458

Rosenthal, J.L., Betka, P.M., Nadin, E.S., and Gillis, R.J, 2015b, Deformational history and fracture intensity of the Iniskin Peninsula, Cook Inlet, Alaska: Geological Society of America, Abstracts with Programs vol. 47, no. 4, p. 21.

Ruppert, N.A., 2008, Stress map for Alaska from earthquake focal mechanisms, in Freymueller, J.T., Haeussler, P.J., Wesson, R.L., and Ekström, Göran, eds., Active tectonics and seismic potential of Alaska: Geophysical Monograph Series, v. 179. doi:10.1029/179GM20

Sinclair, S.W., 1980, Analysis of macroscopic fractures on Teton anticline, northwestern Montana: College Station, TX, Texas A\&M University, M.S. thesis, 102 p.

Wartes, M.A., and Herriott, T.M., 2014, A new occurrence of oil-stained rocks within a small fault zone involving the Middle Jurassic Cynthia Falls Formation, Tuxedni Group, northern Iniskin Peninsula, in Gillis, R.J., ed., Cook Inlet program 2013 field studies_-Observations and preliminary interpretations from new 1:63,360-scale geologic mapping of the Iniskin Peninsula, lower Cook Inlet, Alaska: Alaska Division of Geological \& Geophysical Surveys Preliminary Interpretive Report 2014-2-5, p. 23-27. doi:10.14509/27310

Wilson, F.H., Hults, C.P., Schmoll, H.R., Haeussler, P.J., Schmidt, J.M., Yehle, L.A., and Labay, K.A., compilers, 2012, Geologic map of the Cook Inlet region, Alaska, including parts of the Talkeetna, Talkeetna Mountains, Tyonek, Anchorage, Lake Clark, Kenai, Seward, Iliamna, Seldovia, Mount Katmai, and Afognak 1:250,000-scale quadrangles: U.S. Geological Survey Scientific Investigations Map 3153, pamphlet 76 p., 2 sheets, scale 1:250,000.

Zeng, Lianbo, and Li, Xiang-Yang, 2009, Fractures in sandstone reservoirs with ultra-low permeability-A case study of the Upper Triassic Yanchang Formation in the Ordos Basin, China: AAPG Bulletin, v. 93, p. $461-477$. doi:10.1306/09240808047 